\title{
Palestine and the International Criminal Court
}

\author{
Institutional Failure or Bias?
}

John Dugard*

\begin{abstract}
The International Criminal Court Prosecutor's selection of 'situations' to investigate is highly controversial. Perhaps the most controversial has been the failure of successive Prosecutors to investigate crimes committed by Israel and Hamas in the course of Operation Cast Lead 2008-2009. Initially, this was justified on the ground that Palestine was not a state. In the author's view, this excuse is no longer valid since the recognition of the statehood of Palestine by the General Assembly in November 2012. The failure of the Prosecutor to investigate this situation, and of the Assembly of States Parties to authorize such an investigation when it was requested to do so in November 2012, has resulted in charges of political bias. The author argues that this failure supports the African Union's claim that the Prosecutor's Office has chosen to focus attention on Africa and refused to investigate 'situations' in other continents.
\end{abstract}

\section{Introduction}

The most serious criticism directed at the International Criminal Court (ICC) in the first decade of its existence has been the selection of 'situations'. Apart from the selection of the 'situations' of Darfur and Libya by the United Nations (UN) Security Council for consideration by the ICC, the 'situations' investigated by the ICC have all been chosen by the Prosecutor. Of course, several of these 'situations' have been referred to the ICC by state parties themselves, notably the Democratic Republic of the Congo, Uganda, the Central African Republic and, most recently, Mali. However, as the Prosecutor is under no obligation to accede to a self-referral, such situations are as much selected by the Prosecutor for investigation as the situation in Kenya which was chosen proprio motu by the Prosecutor, Mr Moreno Ocampo.

* Emeritus professor of law, Universities of Leiden and Pretoria; former Member of the International Law Commission and UN Special Rapporteur on the Human Rights Situation in the Occupied Palestinian Territory; Member, Honorary Board of Advisors of this Journal. [john@dugard.nl] 
The power of the Prosecutor to select situations for prosecution is a new one. States and international political organizations decided on the territorial and temporal reach of the situations addressed by tribunals at Nuremberg and Tokyo, and in the former Yugoslavia, Rwanda, Sierra Leone, Cambodia and Lebanon. This means that the ICC Prosecutor's choice of 'situation' is a heavy responsibility and one that is to be exercised independently and without fear or favour. The decisions of both old and new Prosecutors to exclusively concentrate on African situations and to ignore the commission of international crimes in Iraq (by British forces), Colombia (by both the FARC and government forces), the Comoros (by Israel's attack on a ship registered in the Union of the Comoros - the Mavi Marmara) and Palestine, which have been brought to the attention of the Prosecutor's Office, raise doubts about the independence of the Prosecutors and whether they have indeed displayed an antiAfrican bias, as claimed by the African Union, in order to appease European states and the United States, which although not a party to the ICC Statute wields tremendous influence behind the scenes in decision-making in the Court. The refusal of both Prosecutors to investigate the situation in Palestine is particularly disturbing. This is the subject of the present note.

\section{Operation Cast Lead}

It will be recalled that on 27 December 2008 Israel launched an attack on Gaza, code named Operation Cast Lead. This operation which continued until 18 January 2009 resulted in the deaths of 1,400 Palestinians, of whom at least 850 were civilians, including 300 children and 110 women, and the wounding of over 5,000 Palestinians. Fourteen Israelis (including four civilians) were killed and 320 wounded. Over 3,000 Palestinian homes were destroyed, as were hospitals, mosques and schools. Israel employed the most sophisticated modern weaponry, including white phosphorus, in its bombardment of Gaza by land, air and sea. Operation Cast Lead was beamed to homes throughout the world by television. The media provided a blow-by-blow coverage of events. In this sense it was unlike any of the African situations selected for the attention of the ICC where unknown warlords operated with crude weapons in remote areas out of the sight of the media.

Operation Cast Lead was the subject of thorough investigative reports by Human Rights Watch, Amnesty and other NGOs, a Fact Finding Committee appointed by the League of Arab States, ${ }^{1}$ and a UN Fact Finding Mission on the Gaza Conflict established by the Human Rights Council (named the

1 The Report of this Committee of six non-Arab members, of which the author was Chairperson, was published on 30 April 2009 under the title No Safe Place. The executive summary and recommendations are published in C. Meloni and G. Tognoni (eds), Is There a Court for Gaza? A Test Bench for International Justice (T.M.C. Asser Press, Springer, 2012) 586-594. 
'Goldstone Report' after its Chair). ${ }^{2}$ These reports found that the Israel Defense Forces (IDF) had failed to distinguish between civilians and combatants and between civilian objects and military targets and that the loss of life and damage to property were disproportionate to the harm suffered or threatened. The reports also found that serious violations of international humanitarian law had been committed by the IDF, and to a lesser extent by Hamas, and that these violations constituted crimes falling within the jurisdiction of the ICC. Both the Arab League and the Human Rights Council Fact Finding Missions recommended that the situation be investigated by the ICC.

\section{Palestine and the ICC}

On 21 January 2009, the Government of Palestine ${ }^{3}$ made a Declaration in terms of Article 12(3) of the ICC Statute which, for an 'indeterminate' period, recognized the jurisdiction of the ICC 'for the purpose of identifying, prosecuting and judging the authors and accomplices of acts committed in the territory of Palestine since 1 July 2002'. Although the Declaration referred to 'acts' in general it was clearly designed to cover international crimes committed by Israel (and Hamas) in the course of Operation Cast Lead. This Declaration, which accepted the jurisdiction of the ICC by a non-state party, presented the Prosecutor with a golden opportunity to dispel charges of anti-African bias by investigating crimes committed by the military and political leaders of a state that is seen by many African states to be engaged in the practice of colonialism through its settlement enterprise. Moreover, unlike the situations selected in Africa, it was a situation that was well documented with evidence of the commission of international crimes.

Initially, the Prosecutor seemed interested in taking the case despite the obvious uncertainty relating to the question whether Palestine, an entity recognized by some 130 states and a member of the League of Arab States but not a member of the UN, qualified as a state. He met with officials of the Arab League and its Fact Finding Committee to discuss the procedures to be followed. He seemed to have an open mind on the question whether Palestine qualified as a state, not in general but for the purpose of the ICC Statute. In this respect he was clearly mindful of the fact that UN membership was not a pre-requisite for statehood in the ICC as the Cook Islands, a self-governing territory under the sovereignty of New Zealand, was already a party to the Rome Statute. In order to make a determination on the statehood of Palestine he actively encouraged an academic debate on the matter. The present author

2 A/HRC/12/48, 23 September 2009. The executive summary and recommendations of this report are published in Meloni and Tognoni, supra note 1, 173-225.

3 The Declaration referred to above was made by the Minister of Justice of the Palestinian Authority, Mr Ali Khashan, on behalf of the 'Government of Palestine' and not the Palestinian Authority. 
was approached by the editor of the International Herald Tribune, at the instigation of the Prosecutor, to write an op-ed in favour of Palestinian statehood, while Professor George Fletcher of Columbia Law School was commissioned to write an opposing op-ed. ${ }^{4}$ Subsequently, scholars were encouraged to write more scholarly pieces on the subject and to participate in a roundtable session held in the Office of the Prosecutor on 20 October 2010. Erudite articles appeared in law journals and on the ICC website by Alain Pellet, ${ }^{5}$ Malcolm Shaw, ${ }^{6}$ Vera Gowlland-Debbas, ${ }^{7}$ Yael Ronen, ${ }^{8}$ Yuval Shany, ${ }^{9}$ John Quigley ${ }^{10}$ and others. These articles expressed divergent views on whether the Prosecutor should adopt a strict approach to statehood by relying on the criteria for statehood contained in the Montevideo Convention or whether he should instead adopt a functional approach that required a determination to be made with regard to the principal purpose of the Rome Statute - the prosecution of international crimes and the denial of impunity.

Wisely, the Prosecutor paid no attention to the extraordinary op-ed written in April 2011 by Richard Goldstone, the Chair of the Human Rights Council Fact Finding Mission on Gaza, in the Washington Post, in which he purported to withdraw any suggestion in the Report that Israel had targeted civilians 'intentionally' as 'matter of policy.' ${ }^{11}$ As the main findings of all reports was that Israel incurred criminal responsibility by having used force indiscriminately in densely populated areas with recklessness to the foreseeable consequences, without regard to whether Israel intended as a matter of policy to target civilians, Goldstone's 'retraction' failed to impact on the Report of the Human Rights Council. In any event Goldstone's views were repudiated by the three other members of the Fact Finding Mission.

On 3 April 2012, after more than three years of considering the Palestinian Declaration, and shortly before he was to leave office, Prosecutor Moreno Ocampo issued a statement in which he declared that the Office of the Prosecutor had no authority under the Rome Statute to make a decision

4 J. Dugard, 'Take the Case', International Herald Tribune, 22 July 2009 and G.P. Fletcher, 'Don't Go There', International Herald Tribune, 23 July 2009.

5 A. Pellet, 'The Palestinian Declaration and the Jurisdiction of the International Criminal Court', 8 Journal of International Criminal Justice (JICJ) (2010) 981-999.

6 M. Shaw, "The Article 12(3) Declaration of the Palestinian Authority, the ICC and International Law', 9 JICJ (2011) 301-324.

7 V. Gowlland-Debas, 'Note on the Legal Effects of Palestine's Declaration under Article 12(3) of the ICC Statute', published on the ICC website and reproduced in Meloni and Tognoni, supra note $1,513-526$.

8 Y. Ronen, 'ICC Jurisdiction over Acts Committed in the Gaza Strip: Article 12(3) of the ICC Statute and Non-State Entities', 8 JICJ (2010) 3-27.

9 Y. Shany, 'In Defence of Functional Interpretation of Article 12(3) of the Rome Statute: A Response to Yael Ronen', 8 JICJ (2010) 329-343.

10 J. Quigley, 'The Palestinian Declaration to the International Criminal Court: the Statehood Issue', 35 Rutgers Law Records (2009) 1, republished in Meloni and Tognoni, supra note 1, $429-440$

11 'Reconsidering the Goldstone Report on Israel and War Crimes', Washington Post, 1 April 2011. 
whether Palestine qualified as a 'state' under Article 12(3) of the Rome Statute. He explained that:

In interpreting and applying article 12 of the Rome Statute, the Office has assessed that it is for the relevant bodies at the United Nations or the Assembly of States Parties to make the legal determination whether Palestine qualifies as a State for the purpose of acceding to the Rome Statute and thereby enabling the exercise of jurisdiction of the Court under article 12(1). The Rome Statute provides no authority for the Office of the Prosecutor to adopt a method to define the term "State" under article 12(3) which would be at variance with that established for the purpose of article $12(1){ }^{12}$

The Prosecutor did not, however, close the door completely. He acknowledged that the Office of the Prosecutor could in the future consider allegations of crimes committed in Palestine, should competent organs of the UN or eventually the Assembly of States Parties (ASP) resolve the legal issue relevant to the assessment of article $12{ }^{\prime 13}$

The Prosecutor's statement was met with surprise and anger. The question was asked as to why the Prosecutor had needed three years to reach a conclusion that warranted only a two page statement that could have been taken immediately in January 2009 on the Prosecutor's terse reasoning. Inevitably suggestions were made that the Prosecutor had acceded to political pressure, particularly from the United States, to refuse to make such a determination at a time when Palestine's statehood was an issue within the UN.

Acting on the Prosecutor's statement that the ASP might make a determination of Palestine's statehood the present author and Professor William Schabas addressed a letter to the President of the ASP, co-signed by 30 senior international lawyers from 15 countries, which requested the Bureau of the ASP 'in the interests of international criminal justice and the reputation of the International Criminal Court' to place the issue of Palestine's statehood for the purpose of Article 12(3) on the agenda of the ASP at its November 2012 session in The Hague. This was not done. Not only was the matter not placed on the agenda of the ASP, but it was not brought to the attention of the Bureau of the ASP. Instead it seems that the decision to take no action was taken by an inner circle of the Bureau. In short the President of the ASP seems to have suppressed the letter and kept its existence unknown to both Bureau and the ASP itself. There seems little doubt that had the President and her inner circle of advisers brought the request to the Bureau it would have been placed on the agenda of the ASP and in all probability the ASP would have made a determination that Palestine qualified as a state - as the UN General Assembly decided a few weeks later. The difference is that if the ASP had so decided this would have sent out a clear message to the Prosecutor that she should investigate the situation in Palestine.

On 29 November 2012, the UN General Assembly, by 138 votes to 9 with 41 abstentions, decided to accord to Palestine "non-member observer State status

12 ICC, Office of the Prosecutor, Update on the Situation in Palestine, 3 April 2012, $\$ 6$ (italics added).

13 Ibid., $\S 8$. 
in the United Nations. ${ }^{14}$ In effect this means that the determination that Palestine is a state for the purposes of Article 12(3) has been made and that the Prosecutor is now entitled to decide that Palestine is a situation to be investigated. But this has not happened. Instead the Prosecutor has decided to investigate crimes committed in the territory of Mali where the evidence is less clear. ${ }^{15}$ It is rumoured that the Prosecutor will only consider the situation in Palestine when Palestine becomes a party to the Rome Statute. But, of course, this is unnecessary. The Declaration of 21 January 2009 remains in force, and the Prosecutor is free to investigate any international crime that has been committed in the territory of Palestine, whether it be a crime committed in the course of Operation Cast Lead or the crime of transferring settlers into an occupied territory, ${ }^{16}$ a crime that raises no problem of retrospectivity and that has acquired new urgency since the findings of the Human Rights Council Fact-Finding Mission on Israeli Settlements in the Occupied Palestinian Territory which endorses the view that Israel's settlements constitute a serious international crime. ${ }^{17}$

Operation Cast Lead and settlements are not the only Palestinian issues on the desk of the Prosecutor. There is also the case of crimes committed on board the Mavi Marmara by the IDF in 2010 when Israeli commandos boarded a vessel registered in the Union of the Comoros that sought to break the blockade of Gaza and killed nine passengers and wounded many others. ${ }^{18}$ On 14 October 2010, a Turkish NGO, the Turkish Foundation for Human Rights and Freedoms and Humanitarian Relief, filed a complaint with the Prosecutor's Office requesting him to initiate an investigation proprio motu under Article 15 of the Rome Statute. That the ICC has jurisdiction in this case is clear. Article 12(2)(a) of the Rome Statute gives the Court jurisdiction over crimes committed on board a ship registered in a state party. The Union of Comoros is a party to the Rome Statute. To date no action has been taken in response to this complaint.

\section{Setback for Unbiased International Criminal Justice}

This all reflects very badly on the Office of the Prosecutor. Why has it failed to respond to probably the best documented and publicized situation

14 Resolution 67/19.

15 Statement of 16 January 2013.

16 See Art. 8(2)(b)(viii) ICCSt.

17 See paragraph 104 of the Report of the independent international fact-finding mission to investigate the implications of the Israeli settlements on the civil, political, economic and cultural rights of the Palestinian people throughout the Occupied Palestinian Territory, including East Jerusalem, A/HRC/ 22/63, January 2013.

18 See Human Rights Council, Report of the international fact-finding mission to investigate violations of international law, including international humanitarian law and human rights law, resulting from the Israeli attacks on the flotilla of ships carrying humanitarian assistance, A/HRC/15/21, 22 September 2010. 
involving the commission of international crimes? Not because the evidence is unclear: many reports provide abundant evidence of the commission of crimes with the names and circumstances of the victims. Not because the requirement of gravity has not been met: Operation Cast Lead resulted in the death of 1,400 Palestinians, mostly civilians, the wounding of 5,000 and massive destruction to property. The only possible explanation now that the issue of Palestinian statehood has been resolved is that the Prosecutor lacks the strength to confront Israel, and thereby face the ire of the United States and many European states.

The Prosecutor is not the only organ of the ICC that has failed to comply with the vision of the Rome Statute to bring an end to impunity. As shown above the ASP, or rather the President and her close advisers, refused to allow the ASP an opportunity to make a determination on Palestinian statehood that would have sent out a clear message of encouragement to the Prosecutor to take action in response to the Palestinian Declaration. Arguably the Presidency too has a responsibility to do something when the reputation of the ICC is in question. It is common knowledge that President Antonio Cassese intervened in the decision-making of the Prosecutor of the International Criminal Tribunal for the former Yugoslavia in its early days when he - Richard Goldstone - seemed content to prosecute the foot soldiers of the Balkan wars and not to indict the political and military leaders of the conflict. President Cassese rightly believed that this undermined the reputation of the Tribunal, that this was a matter of concern to the Presidency and requested the Prosecutor to change his strategy. Could the Presidency of the ICC not discreetly bring pressure on the Prosecutor to adopt a less selective approach to her task?

This brings me finally to the perception of the African Union that the Office of the Prosecutor is biased against Africa. In pronouncing on this matter one must rely on the available evidence, which shows that both Prosecutors have preferred to target African situations and to avoid non-African situations. Arguments that the killings in Iraq failed to meet the threshold of gravity required cannot be raised in respect of Palestine. This is particularly evident when one compares the case of Kenya, in which the Prosecutor initiated an investigation proprio motu, with that of Palestine. The violence in Kenya in 2007-2008 was not the result of action taken by a disciplined military force using sophisticated modern weaponry, but the result of undisciplined, loosely co-ordinated civil violence. Some 1,200 persons were killed and many wounded, raped and displaced. In the Pre-Trial Chamber, judges were divided as to whether civil violence of this kind could constitute a crime against humanity. Operation Cast Lead, in contrast, was the result of a disciplined military operation, employing sophisticated modern weaponry (including white phosphorus), which failed to distinguish between civilian and military targets in its indiscriminate attacks on densely populated neighbourhoods, hospitals, schools and mosques. More persons were killed, wounded and rendered homeless than in Kenya. Several reports compiled by legal experts have analysed the evidence and concluded that both war crimes and crimes against 
humanity were committed. The failure - and refusal, since 29 November 2012 - of the Prosecutor to investigate crimes committed in Palestine and the determination to proceed with the cases from Kenya and Mail speaks volumes. It speaks of bias. In these circumstances, one must conclude that - on the available evidence - the complaints of the African Union are fully justified.

The relationship between the African Union and the ICC has been soured by the targeting of African situations to the exclusion of non-African situations. The decision of the African Union to confer criminal jurisdiction on the African Court of Justice and Human Rights, although unwise, is a response to this. ${ }^{19}$ There are two ways to heal the wound. Firstly, it is necessary for the ASP to consider this matter in open debate and not to sweep it under the carpet. Secondly, it is incumbent upon the Prosecutor to open the docket of the ICC to non-African situations. Palestine is the obvious starting point.

19 See M. Du Plessis, Implications of the AU Decision to Give the African Court Jurisdiction over International Crimes, Pretoria, Institute for Security Studies, Paper No. 235, June 2012, at 3. See also, D. Akande, M. Du Plessis and C. Jalloh, An African Expert Study on the African Union Concerns about Article 16 of the Rome Statute of the ICC, Pretoria, Institute for Security Studies, May 2010. 